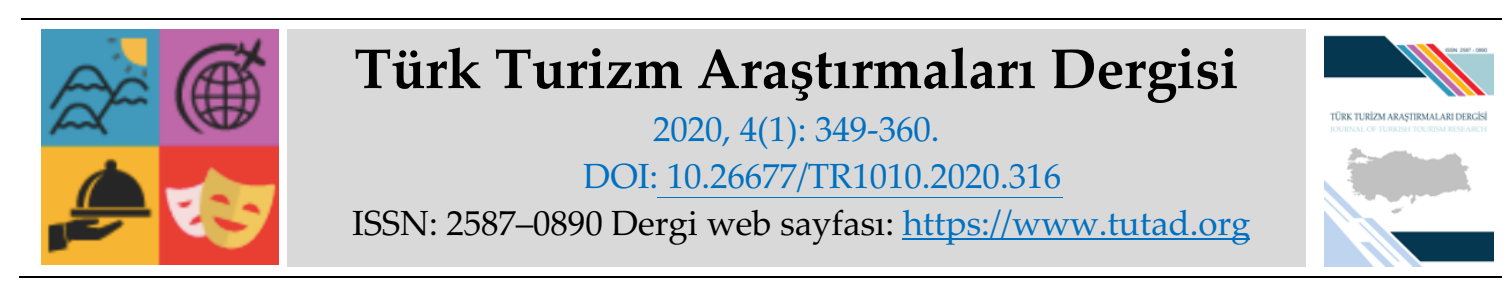

ARAȘTIRMA MAKALESI

\title{
İnanç Turizmi Odağında Benli Sultan Külliyesi Peyzaj Tasarım Önerileri
}

Doç. Dr. Sevgi ÖZTÜRK, Kastamonu Üniversitesi, Mühendislik Mimarlık Fakültesi, Kastamonu, e-posta: sozturk@kastamonu.edu.tr ORCID: https://orcid.org/0000-0002-3383-7822

Arş. Gör. Türkan Sultan YAŞAR İSMAİL, Kastamonu Üniversitesi, Mühendislik Mimarlık Fakültesi, Kastamonu, e-posta: tsyasar@kastamonu.edu.tr ORCID: https://orcid.org/0000-0002-0184-0349

Arş. Gör. Öznur IŞINKARALAR, Kastamonu Üniversitesi, Mühendislik Mimarlık Fakültesi, Kastamonu, e-posta: obulan@kastamonu.edu.tr

ORCID: https://orcid.org/0000-0001-9774-5137

\section{$\ddot{O} z$}

İnsanlık tarihi kadar eski olan din olgusu, bireylerin temel fiziksel ihtiyaçlarını karşılamasından sonra kendi varoluşlarını sorgulamasıyla ortaya çıkmıştır. Önemli dini merkezler binlerce yıldır o dinlere mensup insanlar tarafından ziyaret edilmektedir. Bu açıdan bakıldığında, inanç turizminin ilk ortaya çıan turizm türlerinden biri olduğu söylenebilir. Araştırmanın yürütüldüğü Kastamonu şehri; neolitik dönemden günümüze farklı medeniyetlere ev sahipliği yapmış olup inanç turizm değerleri açısından zengindir. Bu bağlamda araştırmada Benli Sultan Külliyesi inanç turizmi odağında ele alınmış, külliye ve yakın çevresinin doğal, kültürel ve tarihi değerlerine uygun tasarım yaklaşımları ile öneriler sunulmuştur.

Anahtar Kelimeler: İnanç Turizmi, Benli Sultan Külliyesi, Konsept yaklaşımlar.

Makale Gönderme Tarihi: 18.10.2019

Makale Kabul Tarihi: 03.01.2020

\section{Önerilen Atıf:}

Öztürk, S., Yaşar İsmail, T. S. ve Işınkaralar, Ö. (2020). İnanç Turizmi Odağında Benli Sultan Külliyesi Peyzaj Tasarım Önerileri, Türk Turizm Araştırmaları Dergisi, 4(1): 349-360.

(C) 2020 Türk Turizm Araştırmaları Dergisi. 


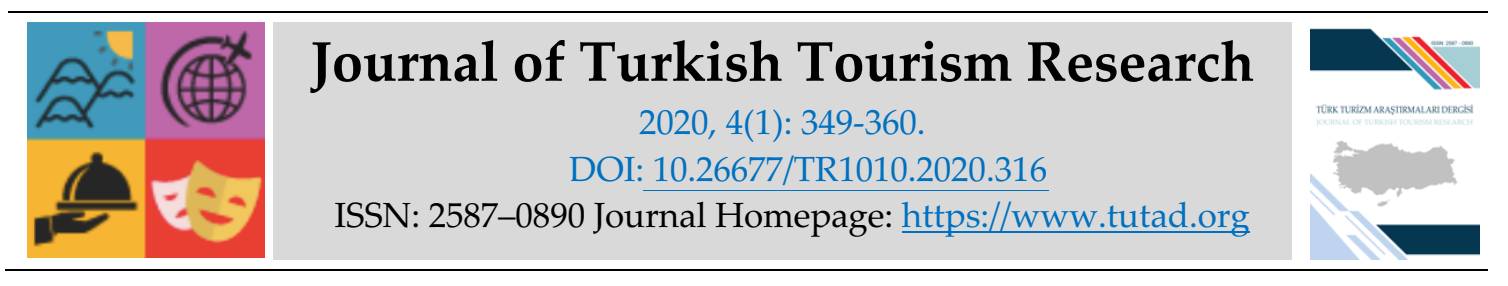

RESEARCH PAPER

\title{
Proposals of Landscape Design Concepts in Benli Sultan Complex in the Context of Religious Tourism
}

Associate Prof. Dr. Sevgi ÖZTÜRK, Kastamonu University, Faculty of Engineering and Architecture, Kastamonu, e-mail: sozturk@kastamonu.edu.tr

ORCID: https://orcid.org/0000-0002-3383-7822

Research Assistant Türkan Sultan YAŞAR İSMAİL, Kastamonu University, Faculty of Engineering and Architecture, Kastamonu, e-mail: tsyasar@kastamonu.edu.tr

ORCID: https://orcid.org/0000-0002-0184-0349

Research Assistant Öznur IŞINKARALAR, Kastamonu University, Faculty of Engineering and Architecture, Kastamonu, e-mail: obulan@kastamonu.edu.tr

ORCID: https://orcid.org/0000-0001-9774-5137

\begin{abstract}
The religion, which is as old as the history of humanity, arose right after the questioning the individuals' own existence after meeting the basic physical needs of individuals. Important religious centres have been visited by people belonging to those faiths for thousands of years. From this perspective, it can be said that faith tourism is one of the first emerging tourism types. The city of Kastamonu; has been the home to different civilizations from the Neolithic period to the present day and it has rich resources in terms of religious tourism. In this context, the Benli Sultan Complex was examined within the context of religious tourism. Design proposals were made of in accordance with the design approaches appropriate to the natural, cultural and historical values of the space and its immediate surroundings.
\end{abstract}

Keywords: Religious Tourism, Benli Sultan Complex, Conceptual Approaches.

Received: 18.10 .2019

Accepted: 03.01.2020

\section{Suggested Citation:}

Öztürk, S., Yaşar İsmail, T. S., and Işınkaralar, Ö. (2020). Proposals of Landscape Design Concepts in Benli Sultan Complex in the Context of Religious Tourism, Journal of Turkish Tourism Research, 4(1): 349-360.

(c) 2020 Türk Turizm Araştırmaları Dergisi. 


\section{Gíriş}

Günümüzde küresel pazar ekonomisinin zorunlu bir şartı olarak rekabet koşullarına uyum sağlamak amacıyla ülkeler ekonomik öncelikli gelişme stratejilerini ön planda tutmaktadır (Bahçe, 2011; Sabır, 2013). Sanayi Devriminin gerçekleşmesiyle beraber ortaya çıkan üretim odaklı büyüme politikaları yerini günümüzde bilgi toplumuna geçiş sürecine paralel olarak hizmetler sektörüne bırakmaktadır. Özellikle 1980'li yıllardan sonra üretilen neo-liberal politikalar ve küreselleşme bağlamında kentlerin kendine yeniden senaryo tanımlaması, güncel paradigmalar geliştirmesi ve farklı araçlarla ifade etmesi gerekli olmuştur (Engincan, 2016; Akturan ve Oğuztimur, 2016).

Kentlerin markalaşması ve kapitalistleşen ülkelerin düzeyinde sermaye seçerek başarıyı yakalaması sürecinde turizm önemli bir uluslararası argüman niteliğinde olup kentsel mekanlar pek çok ürün gibi pazarlanmaktadır (Kavaratzis, 2004). Amaç, kentlerdeki yatırımların ve turizm gelirlerinin artırılması ve toplumun geliştirilmesidir (Akturan ve Oğuztimur, 2016). Bu nedenle kalkınma süreçlerinde turizmin geçmişten günümüze eğilimini anlamak ve buna bağlı olarak potansiyelleri sistematik olarak ele almak önem arz etmektedir.

Dünyada yaşanan birtakım gelişmeler, turizmde yeni paradigmalar doğmasına yol açmıştır. Bu gelişmelerin başında, üretim sisteminde emek/sermaye ilişkisine ilişkin postmodern bakışlar, beraberinde hızla yaygınlaşan sürdürülebilirlik tartışmaları ve seyahat motivasyonları gelmektedir. Önceleri sadece imalat sanayinde tartışılan sürdürülebilirlik tartışmalarının da etkisiyle, 2000'li yıllara gelindiğinde turizm de modern dönemdeki kitlesel nitelikten hızla uzaklaşarak, bireyselliğe doğru yönelmiştir. Turistlerin değişken ve istikrarsız talebine cevap verebilme çabaları neticesinde turizm olgusu da postfordist bir çerçevede ele alınmaya başlanmış, bu durum güncel turizm modellerinin gelişmesini sağlamıştır (McIntyre, 1993; Urry, 2009; Kozak vd., 2012).

Diğer yandan ulaşım-iletişim sektörlerinde yaşanan gelişmelere bağlı olarak dünyanın izafi olarak küçülmesi ve gelişen seyahat motivasyonları, turizm türlerindeki dinamik yapıyı tetikleyerek turizm çeşitliliğini etkilemiştir (Alaeddinoglu ve Aliağaoğlu, 2005). Tartışmalar yoğun turist talebinin kısa zaman içerisinde büyük ölçeklerde tüketimine dayanan kitle turizmine odaklanmaktadır. Artan çevresel bilinç neticesinde doğal çevreye olan görsel, çevresel ve kültürel zararları eleştirilmektedir (Ovalı, 2007).

Kitle turizminden farklılaşan yapısıyla gündeme gelen turizm türleri eko-turizm, yeşil turizm, kırsal turizm, çiftlik turizmi, kongre turizmi, çevre dostu/ çevreye duyarlı turizm, sorumlu turizm, inanç turizmi gibi alternatif turizm modelleriyle ortaya çıkmış terimler bulunmaktadır (Boo, 1990; Cater ve Lowman, 1994; Ovalı, 2007; Butowski, 2012; Arslaner ve Erol, 2017). Alternatif turizm türlerinden biri de ilgili literatürde dini turizm olarak da adlandırılan inanç turizmidir. İnanç turizminin kültür turizmiyle ayrımını yapmak zorlaşabilmektedir (Richards, 2007; Eykay, 2015). Özellikle kültür, miras ve inanç turizmi birbirlerinin gelişimleri destekleyerek, yeni turizm türleri içerisinde en hızlı gelişme gösteren turizm formları olarak ifade edilir. Turizmle inanç arasında geçmişten günümüze yakın bir ilişki söz konusudur. Çünkü erken dönemlerden beri inanç, seyahat için güçlü bir motivasyon kaynağı olmuştur (Henderson, 2002; Okuyucu ve Somoncu, 2013).

Son yıllarda inanç turizmi merkezlerinde yapılan restorasyon ve çevre düzenleme çalışmaları ziyaretçi sayısını artırmıştır. PEW Araştırma Merkezi'nin 2010 yılında yaptığı bir araştırmaya göre, dünya genelinde Hıristiyan, İslam, Hinduizm, Budizm ve Yahudi dinine mensup yaklaşık 5,5 milyar insan yaşamaktadır. Bu durum, inanç turizmi pazarının büyüklüğünü ve önemini 
göstermektedir (Erbaş, 2002; Olcay ve Albuz, 2016). İnanç turizminin ilk bileşeni olan hac, sıklıkla, binlerce yıl öncesine dayanan en eski turizm şekli olarak kabul edilmektedir (Tala ve Padurean, 2008).

Küresel ölçekte bakıldığında dünya, ilginç bir din mozaiği düzlemidir. Mezopotamya topraklarının bir parçası olan Anadolu, Hristiyanlık, İslamiyet gibi semavi dinlerin önemli merkezlerinden biri olmuştur. Geçmişinden gelen bu zenginlikle, Türkiye hem yerel inançlara hem de 3 büyük semavi dine ait kutsal kabul edilen pek çok tapınaklara, kiliselere, camilere, sinagoglara, türbelere sahiptir (İbret, Aydınözü ve Uğurlu, 2015). Bu bağlamda Kültür ve Turizm Bakanlığı "Türkiye Geneli Korunması Gerekli Taşınmaz Kültür Varlığı İstatistiği" Türkiye'de 9.403 dinsel yapının olduğunu göstermektedir (Türker vd., 2019; Olcay ve Albuz, 2016:15).

Dini yapıları ziyaret eden insanlar mekan ve çevresi ile ilişki kurmakta ve mekanlarla kendilerini özdeşleştirmektedirler. Dini mekan ve aidiyet kavramı son yıllarda mekan psikolojisi kapsamında sıklıkla araştırılan konulardan biridir (Herzog vd., 2011; Mazumdar ve Mazumdar, 2012; Neitz, 2013; Benjamin ve Meagher, 2018). İnanç turizmi kapsaminda Hristiyanlık, İslamiyet, Budizm ve Hinduizm dinlerine yönelik tasarlanmış mimari yapılar ve peyzaj düzenlemelerinin ziyaretçiler üzerinde ne gibi etkileri olduğunu araştıran birtakım çalışmalar yapılmıştır (Shinde, 2011; McGettigan ve Griffin, 2012; Devi ve Koacher, 2013; Lopez, 2013; Taher, 2016; Lopez vd., 2017).

Olcay ve Albuz (2016) Türkiye'deki inanç turizm potansiyeline vurgu yaparak tanıtıma katkısını ortaya koymaktadır. Anadolu'da önemli inanç turizmi merkezleri denildiğinde İstanbul, Konya, İznik, Antakya ve Şanlıurfa akla gelen ilk şehirlerdir. Kastamonu ili de inanç turizm noktasında her geçen gün adını duyurmaya başlamış önemli bir Anadolu kentidir (İbret vd., 2012).

Günümüz ziyaretçi beklentilerinin hızla geliştiği ve çeşitlendiği bu dönemde turistlerin de işletmelerden beklentileri çeşitlenmektedir (Dönmez ve Türkmen, 2015). Mekansal beklentiler turizm kaynaklarının ele alınışında farklı bakış açılarını beraberinde getirmektedir. $\mathrm{Bu}$ bağlamda araştırmada Kastamonu İlinin turizm değerleri arasında yer alan ve inanç turizmi kapsamında önemli merkezlerden biri olan Benli Sultan Külliyesi farklı konsept çalışmalarıyla ele alınmıştır.

\section{MATERYAL ve YÖNTEM}

Kastamonu, Anadolu'nun Türkleştirilme serüveninde öne çıkan kentlerinden biridir ve günümüzde Türk-İslam eserlerinin önemli örneklerine ev sahipliği yapmaktadır. İl sınırları içinde Selçuklu, Candaroğulları ve Osmanlı dönemine ait birçok külliye, cami, türbe ve dergah bulunmaktadır. Önemli din erbaplarına da ev sahipliği yapmış olan kent, bu özelliği ile inanç turizmi çerçevesinde yerli turistlerin ilgi gösterdiği şehirlerden birisidir (İbret vd., 2015). Kastamonu Ilgaz Dağı'nın kuzeyindeki Ahlat Köyü sınırları içerisinde yer alan Benli Sultan Külliyesi, inanç turizmi kapsamında en çok ziyaretçi çeken yerlerden birisidir.

2018 verilerine göre Ahlat Köyü'nde 176 kişi yaşamaktadır ve geçimlerini hayvancılık, ormancılık ve arıcılık yaparak sağlamaktadırlar. Köy sakinleri ile yapılan görüşmelerde köyde esnaf ya da işletme sahibinin bulunmadığı öğrenilmiştir. Köy halkı ihtiyaçlarını kent merkezine giderek karşılamaktadır (TÜİK, 2018). 

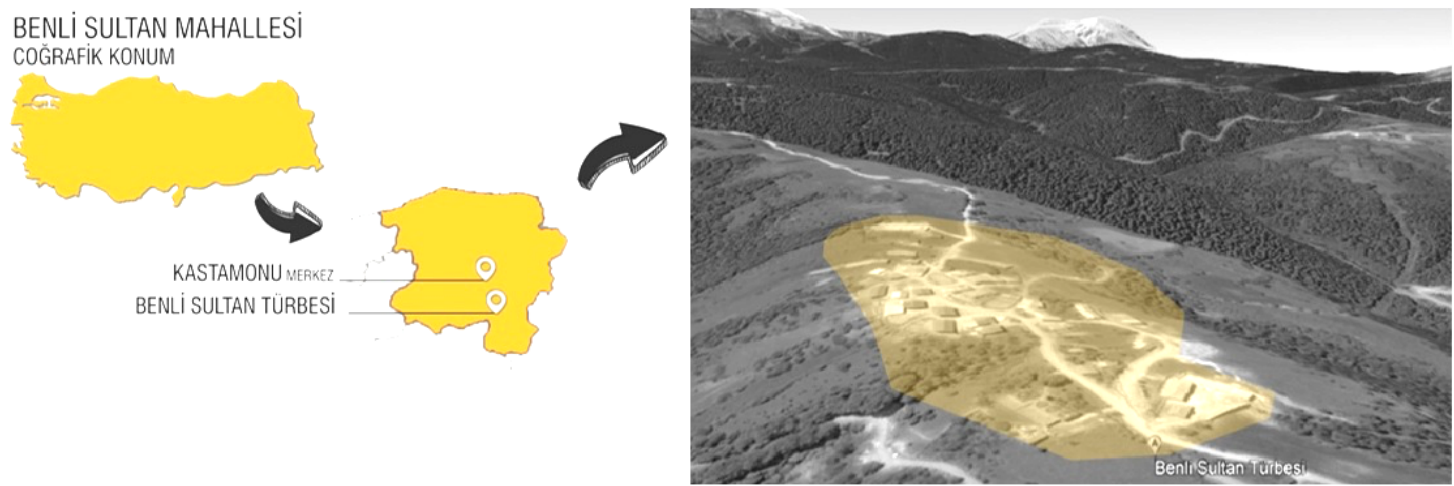

Şekil 1. Çalışma Alanının Konumu

Bu çalışmaya konu olan Benli Sultan tam ismiyle Ebu Şame Şeyh Muhyiddin Muhammed, Kastamonu Vakıflar Bölge Müdürlügü̈'ndeki kayıtlara göre 2. Selim döneminde yaşamış olan bir tasavvuf erbabıdır. Farklı kaynaklara göre kendisinin Nakşibendi/Halveti tarikatlarına bağlı olduğundan bahsedilmektedir. Benli Sultan Kastamonu'ya yerleştikten sonra bulunduğu köy onun adını almış ve 1512-1520 yılları arasında köye cami, mutfak, misafirhane, kütüphane ve türbeden oluşan bir külliye kompleksi inşa edilmiştir (Kastamonu Kültür ve Turizm Müdürlüğü, 2019). Birçok mucize ve hikmet hikayesine konu olan Benli Sultan, Kastamonu'daki önemli evliyalardan birisidir ve külliyesi il içi ve dişından en çok ziyaretçi çeken noktalardan biridir.

Kastamonu'da 5-8 Mayıs tarihleri arasında kutlanan Evliyalar Haftası'nda Benli Sultan Türbesi'ne gelen ziyaretçi sayısı 5000'i bulabilmektedir. Bu tarihlerde Vakıflar Genel Müdürlüğü tarafından stantlar açlıp kitap satışı gerçekleştirilmektedir. Aynı zamanda Belediye köye gelen misafirlere yemek dağıtmaktadır. Ayrıca, hafta sonları ve bayramlarda da yakın çevreden ziyaretçiler gelmektedir. Bununla birlikte, ziyaretçilere yönelik sürekli bir hizmet bulunmamaktadır.

Alanın dini açıdan önemli bir mekan olmasından hareketle, Kastamonu Üniversitesi Mühendislik ve Mimarlık Fakültesi Peyzaj Mimarlığı Bölümü 2. sınıf öğrencileri 2018-2019 Bahar yarıyılında Peyzaj Tasarım Projesi III (PTP III) dersi kapsamında Benli Sultan Külliyesi Meydan Tasarımı Projesini hazırlamışlardır. Proje kapsamında öncelikle Ahlat Köyü Benli Sultan Mahallesi ziyaret edilmiş ve alanın mevcut durumu incelenerek sörvey/analiz paftaları oluşturulmuştur.

Elde edilen veriler ışığında alan ve çevresinin doğal, kültürel ve tarihi değerlerine uygun tasarım konsept önerileri geliştirilmiştir. Geliştirilen konsept yaklaşımı ve fiziksel veriler ele alınarak, alanda bulunan külliye, asa suyu bölgesi ve Kastamonu Belediyesi'nin inşa ettiği kurban kesim alanını kapsayan meydan tasarımları şekillenmiştir. Proje tasarımlarında alana gelen ziyaretçi sayısı, alanda yapılan aktiviteler ve burada geçirilen zaman göz önüne alınmıştır.

\section{PROJE ÖRNEKLERI VE YAKLAŞIMLAR}

Benli Sultan Külliyesinde ilk rölöve çalışması 1987 yılında gerçekleştirilmiştir. 1994 yılında yangın sonucu Vakıflar Genel Müdürlüğ̈ tarafından restore edildikten sonra 2017 yılında yeni bir restorasyon projesi hazırlanmıştır. Proje kapsamında Türbe ve çevresinde iyileştirme çalışmaları yapılmıştır. Ancak mevcut restorasyon projesi detaylı ve yenilikçi bir peyzaj 
çalışmasını kapsamamaktadır. Bu kapsamda yürütülen PTP III dersi öğrencileri tarafından tespit edilen sorunlar aşağıda ifade edilmiştir:

- Köyün girişinde bulunan Külliyenin mekansal algısı yetersizdir,

- Külliye girişi tanımsız olup sert zemin yumuşak zemin fark edilmemektedir,

- Külliye çevresinde tanımlı bir meydan toplanma alanı yoktur,

- $\quad$ Alanda otopark bulunmamaktadır. Özellikle ziyaretçi sayısının çok fazla olduğu belirli günlerde sorun iyice fark edilmektedir,

- $\quad$ Külliye ve çevresinde yaya sirkülasyonu da sert zeminlerin tanımsız olması ve kot farkları yüzünden sekteye uğramaktadır,

- $\quad$ Alanda ziyaretçiler için yeterli sayıda tuvalet bulunmamaktadır. Mevcut tuvaletlerin konumu alanda önemli bir nokta olan asa suyu bölgesi yanındadır ve görsel kirlilik oluşturmaktadır,

- Ahlat Köyü'nde yaşayan yerel halkın ek gelir elde etmesini sağlayacak bir mekan ya da etkinlik alanı tanımlanmamıştır.

Kastamonu Üniversitesi Peyzaj Mimarlığı Bölümü'nde öğrencilerin ders yürütücüleri ile birlikte hazırladığı tasarım önerileri, Benli Sultan Türbesi'nin ruhaniyetine paralel olarak ziyaretçilere alanın değerleri hakkında hem bilgi verip hem de daha verimli zaman geçirmelerini sağlamayı amaçlamaktadır. Bu çalışma kapsamında sekiz adet özgün peyzaj tasarım projesi üretilmiştir. Alandaki mevcut sorunlara yönelik çözümler oluşturulmuş ve yenilikçi öneriler getirilmiştir. Projelerin üretim aşamalarında aşağıdaki adımlar izlenmiştir.

- Alana ait verileri ortaya koyan sörvey çalışması,

- Alandaki mevcut durumu peyzaj mimarı gözüyle irdeleyen analiz çalışması,

- Alanın kaynak değerlerine uygun özgün konsept fikirlerinin oluşturulması. Her bir konsepte bağlı olarak ziyaretçilerin Benli Sultan Külliyesi ve çevresinde daha verimli zaman geçirmelerini sağlayacak yeni etkinlik önerilerinin getirilmesi.

- Bitkilendirme projesi önerisinin oluşturulması,

- Alt yapı uygulamaları ve detayların içeren yapısal proje,

- Nihai kesin projenin çizimi. Kesin projede külliye çevresindeki araç ve yaya sirkülasyonu, eklenmesi önerilen donatı ve strüktürler, malzeme seçimi olarak ifade edilmektedir.

Yukarıda bahsedilen adımlar izlenerek oluşturulmuş iki örnek proje aşağıda sunulmuştur;

\section{Yıldız Konseptli Proje Tasarımı}

İslam dininde yıldız formu mimarinin yapılarda dekorasyon öğesi olarak sıklıkla kullanıldığ görülmektedir. Hayvan ve insan figürlerinin kullanımı yasak olduğu için yıldız gibi geometrik formlar sıklıkla tercih edilmiştir. Dekoratif amacı haricinde, yıldızlar Allah'ın varlığının delillerindendir ve Kuran'da sıklikla yıldızların yeri ve konumundan bahsedilmektedir. Göklerin nurunu yansıtan Güneş gibi yıldızlar, tasavvuf eğitiminde birer metafor olarak kullanılmaktadır. Aynı zamanda, kimi kaynaklarda yıldız formu Hz. Süleyman'ın mührü olarak ifade edilmiştir. 
Proje kapsamında oluşturulan etkinlik alanlarında, seçilen konseptteki manevi ruhun yansıtılması amaçlanmıştır. Vurgusu olmayan külliye girişi, ön kısımda bulunan mezarlık ve doğal bitki örtüsü dikkate alınarak tek bir noktadan verilmiştir. Doğa ile bir olmak, yaratanı yarattıkları ile anlamak fikrinden yola çıkılarak alanda duyu bahçeleri oluşturulmuştur. Benli Sultan'ın yıllar boyu bir ağaç kovuğunda inzivaya çekilmesinden ilham alarak, alandaki ormanlık alan içerisine inziva odaları yerleştirilmiştir. Külliyeden bu inziva odalarına geçişte su öğesi kullanılmış, suyun terapi edici özelliğinden yararlanılmıştır. Külliye ve çevresinde bitki seçiminde İslami dönem bahçelerinde kullanılan ve iklimsel verilere uygun tür seçimi tercih edilmiştir. Külliyede daha önce bulunan ancak 20. yüzyılda çıkan bir yangın sonucu yok olan kütüphanenin yeniden hayata geçmesi için yıldız formlarından esinlenerek tek katlı bir kütüphane binası tasarlanmıştır. Ayrıca bu kütüphanenin girişinde alanı tanıtıcı bir barkovizyon gösterimi düşünülmüştür.

Konsepte bağlı etkinlik alanlarının haricinde, alana araçlarıyla gelen ziyaretçiler için tasarlanan otopark külliyenin karşı tarafına konumlandırılmıştır. Park eden araçların doğal çevrede görüntü kirliliği yaratmasını engellemek adına otopark alanının üzerinde bir çatı bahçesi çözümlenmiştir. Çocukları ile alanı ziyaret edenler için türbe binasından uzak bir nokta olan çatı bahçesinin yanında bir çocuk oyun alanı çözülmüştür. Yeme-içme birimlerinin odağında ziyaretçilerin dinlenebilecekleri, belirli zamanlarda farklı gösterileri izleyebilecekleri küçük ölçekli bir amfi ayrıca düşünülmüştür.

Yapısal elemanlardan kentsel donatı ölçeğine kadar projedeki tüm birimler konsepte uygun çizgilerde alana özel olarak tasarlanmıştır. Projenin en önemli amacı, her yaştan ziyaretçilerin etkin vakit geçirebilecekleri ibadetlerini gerçekleştirebilecekleri bir mekan oluşturmaktır.

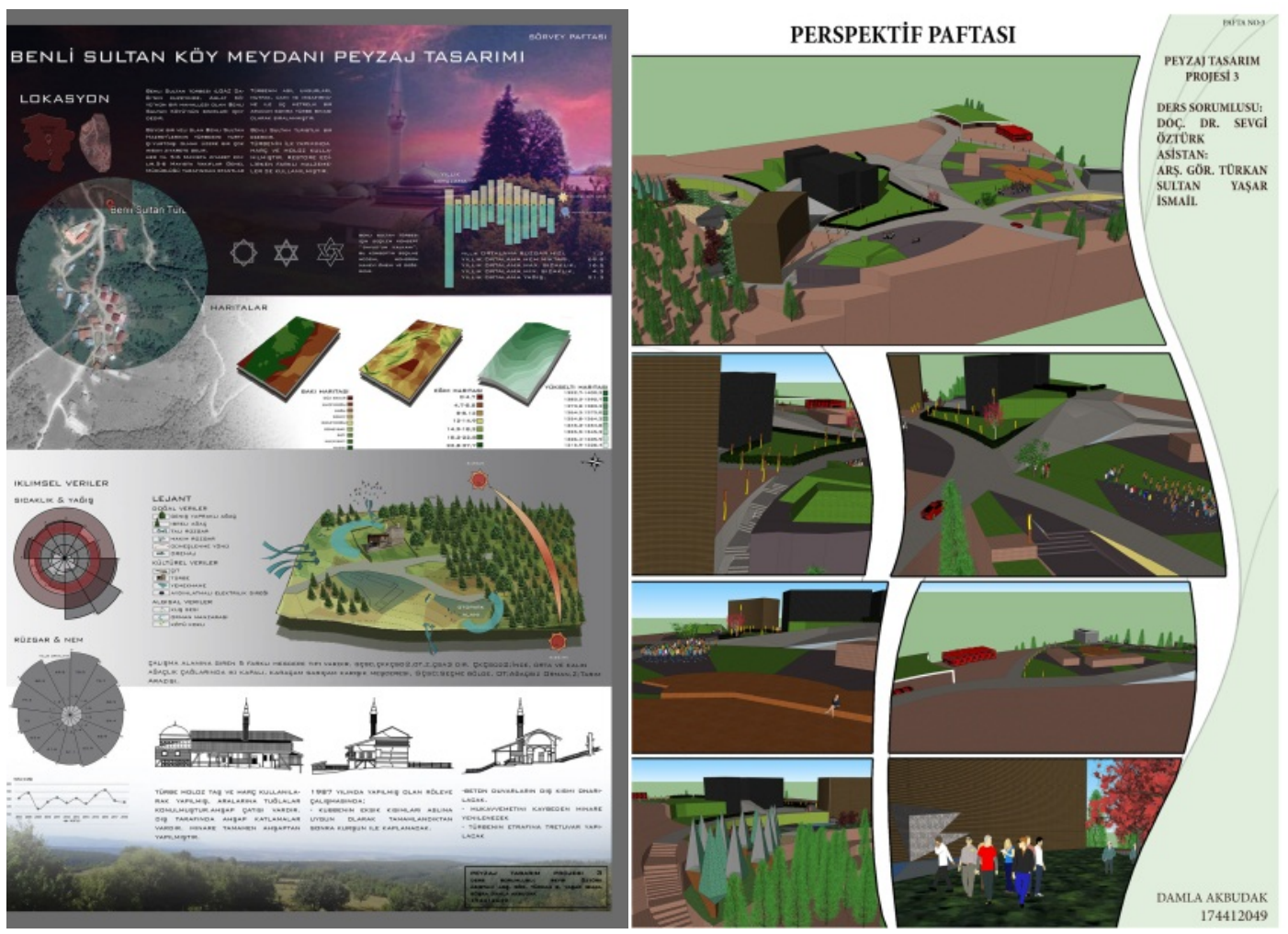



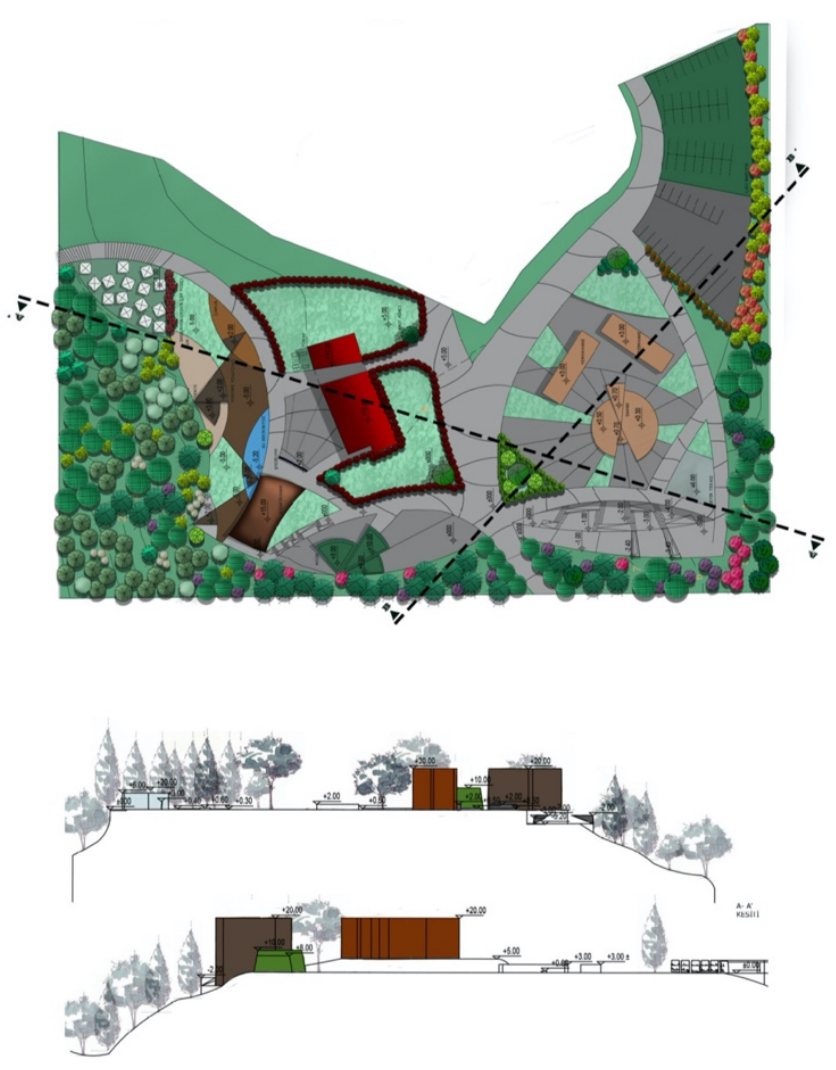

Şekil 2. Yıldız Konseptli Tasarım Projesinin Sörvey/Analiz, Kesin Proje, Perspektif ve Detay Paftaları

\section{Düğüm Konseptli Proje Tasarımı}

Dügüm konseptli peyzaj tasarımı projesinde Benli Sultan Türbesi'nin insanların ibadet etmek için bir araya geldiği ortak nokta olması özelliğinden yola çıkılmıştır. Ziyaretçilerin aynı yerde toplanması kalabalık bir düğümü anımsatmaktadır. Aynı zamanda, meydanların kentsel yapının en belirgin bileşeni olması, insanların toplandığı yer, yani düğüm noktası olması nedeniyle alandaki meydan projenin odak noktası olarak alınmıştır. Meydan haricinde yine alanda toplanılan önemli (Benli Sultan Türbesi, Asa Suyu vb.) alt dügüum noktaları tespit edilmiş ve konsepte uygun olarak farklı aktivitelerle tanımlanmıştır. Konseptin tasarıma aktarılmasında düğüm formunun saçaklarından ortaya çıkan çizgisel formlardan yararlanılmıştır.

Alanın girişinde Benli Sultan hakkında bilgi veren interaktif bir müze binası tasarlanmıştır. Özellikle ziyaretçilerin yoğun olduğu belirli dönemlere yönelik hem tur araçları hem de özel araçlar için otopark (110 kapasiteli) çözümlendirilmiştir. Otopark, yeme-içme birimlerinin yanında tasarlanmış, Külliyenin görsel kalitesine zarar vermemesi göz önünde tutulmuştur. Yeme-içme birimlerinin yakınında ayrıca, yerel halkın ürettikleri doğal ürünleri satabilmeleri ve köy halkına alternatif geçim kaynağı yaratabilmek için meydan çevresinde bir köy pazarı da oluşturulmuştur. Alanın güney tarafında topoğrafyanın hafif eğimli olduğu bölümünde çocuklara yönelik bir oyun alanı tasarlanmışır. Bu projede de yine ziyaretçilerin ibadetlerini yaptıkları esnada çocukların da iyi vakit geçirmeleri düşünülerek tüm yaş gruplarına etkinlik sunulması hedeflenmiştir. 

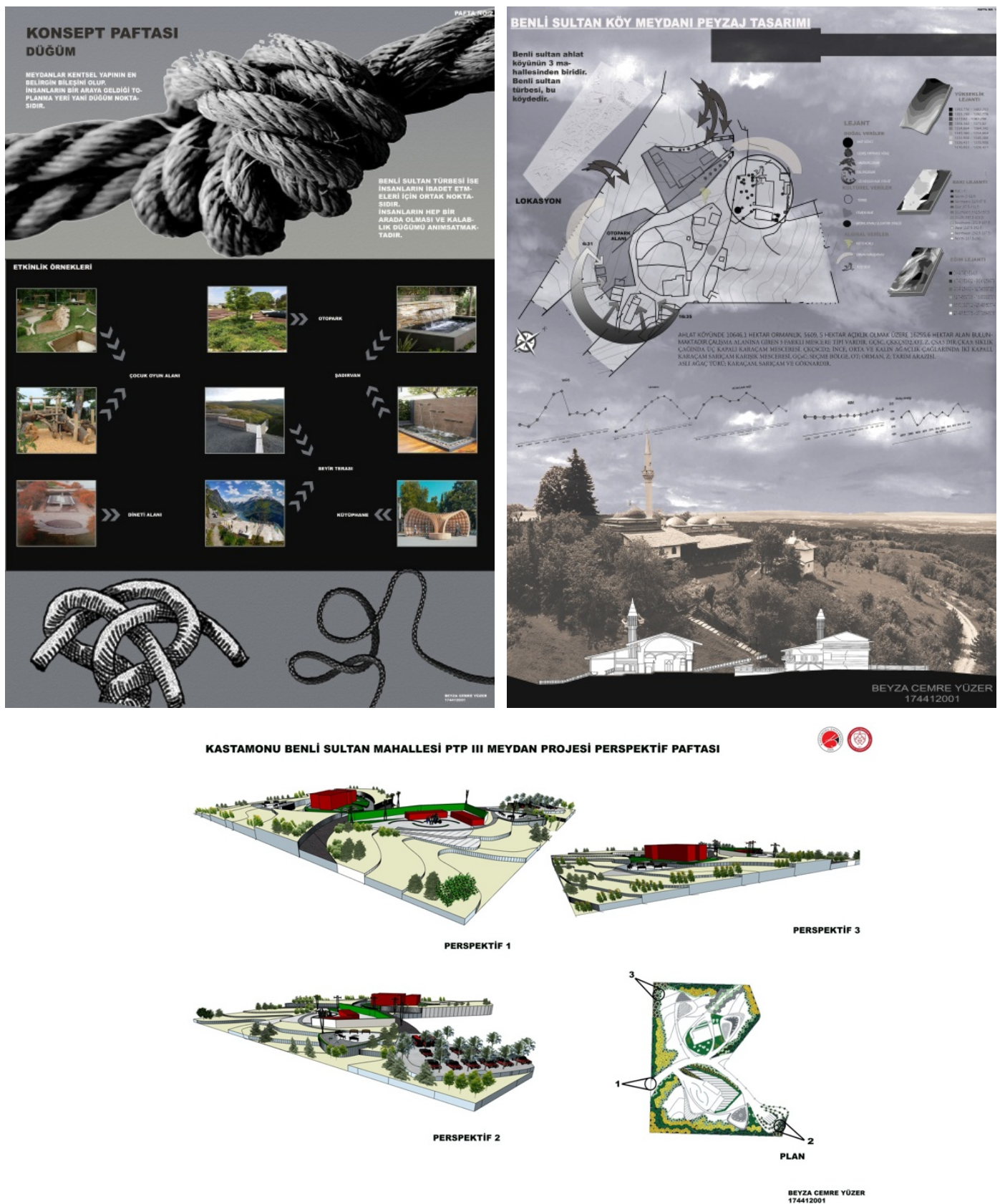

Şekil 3. Dügüm Konseptli Tasarım Projesinin Sörvey/Analiz, Konsept, Kesin Proje ve Perspektif Paftaları

\section{SONUÇ}

Kastamonu inanç turizmi potansiyeli yüksek olan bir coğrafyadır. Benli Sultan Külliyesi Kastamonu'nun önemli inanç turizmi mekanlarından biridir. Nitekim, Türker vd., (2019) yerli turistlerin dini mekânları ziyaret etme motivasyonlarını belirlemek amacıyla yaptığı çalışmaya göre; Benli Sultan Külliyesi, Kastamonu'da dini amaçla ziyaret edilen yerler arasında 8. sırada yer almaktadır. Kastamonu'nun önemli inanç turizmi değerlerinden biri olan Benli Sultan Külliyesi ile ilgili peyzaj projesi geliştirilmesinin amaçlandığı bu araştırma Kastamonu Üniversitesi Peyzaj Mimarlığı Bölümü'nde PTP III dersi kapsamında gerçekleştirilmiştir. Proje 
kapsamında külliyede alan araştırması yapılmış ve birçok sorun tespit edilmiştir. Bu çalışmada projeler bahsedilen sorunlar baz alınarak tasarlanmıştır (Tablo 1). Tasarım yaklaşımları, özellikle külliyenin alansan algısı, anıt ağacın korunması, dini alanlarda kullanılan bitki seçimi, yöre halkının projeye dahil edilmesi gibi birincil prensipler odağında ortaya konmaya çalışılmıştır.

Tablo 1. Alana Yönelik İhtiyaç Duyulan Mekanların Benli Sultan Külliyesi'nin Mevcut Hali ve Proje Önerileri Sonrasındaki Karşılaştırılması

\begin{tabular}{|l|l|l|}
\hline Alandaki İhtiyaçlar & $\begin{array}{l}\text { Benli Sultan Külliyesi Mevcut } \\
\text { Hali }\end{array}$ & $\begin{array}{l}\text { Çalışma Kapsamında } \\
\text { Geliştirilen Proje Önerileri }\end{array}$ \\
\hline Tanımlı Giriş & Yok & Var \\
\hline Otopark Alanı & Yok & Var (Ort. 110 Araçlık) \\
\hline Toplanma Alanı & Yetersiz ve Tanımsız & Var \\
\hline Etkinlik Alanı & Yok & Var (Meydan, Amfi) \\
\hline Alan Hak. Bilgilendirme & Yetersiz & Var (Tabela, Müze, Sergi A.) \\
\hline Köy Halkı İçin Gelir Kay. & Yok & Var (Köy Pazarı) \\
\hline Çocuk Oyun Alanı & Yok & Var \\
\hline Tuvaletler & Yetersiz & Var \\
\hline Sirkülasyon Alanları & Tanımsız & Var \\
\hline
\end{tabular}

Mekanın öneminin vurgulanması ve sahip olduğu unsurların analiz edilmesiyle mekan ve yakın çevresinin doğal, kültürel ve tarihi değerlerine uygun tasarım konsepti önerileri geliştirilmiştir. Yürütülen çalışmada, yıldız ve düğüm olmak üzere iki temel konsept çerçevesinde öneriler sunulmuştur. Böylece tasarımsal bileşenlerin mekana kazandırılmasıyla alanın turizm değerinin güçlendirilmesi hedeflenmiştir. Bu çalışma kapsamında geliştirilen proje önerilerinin Benli Sultan Külliyesi'ne ileride yapılacak olan çevre düzenleme çalışmalarına rehber olması amaçlanmıştır. İnanç turizmi kapsamında değerlendirilen dini mekanlarda yapılacak doğru peyzaj tasarımları bu alanların etkin kullanımını sağlamaktadır. Kullanıcı istek ve ihtiyaçlarını göz önüne alarak özgün projeler geliştiren peyzaj mimarlarının mekanın kimliğine katkıda bulunacak ve ziyaretçilerin aidiyet hissini artıracak çalışmalara katkısı yadsınamazdır. Yukarıda bahsedilen sebeplerden dolayo peyzaj mimarlarının dini mekan çevre düzenleme çalışmalarında daha çok söz sahibi olması gerekmektedir.

\section{KAYNAKÇA}

Akturan U. ve Oğuztimur S. (2016). Kent Markalaşması Kavramının İçeriği ve Gelişimi: Farklı Disiplinler Farklı Yaklaşımlar. Planlama, 26(2), 117-129.

Alaeddinoğlu, F. ve Aliağaoğlu, A. (2005). Turizmde Planlama ve Türkiye'de Turizm Planlaması: Turizm Planlarının Etkinliği ve Başarılarına İlişkin Bir Değerlendirme. Erdem Atatürk Kültür Merkezi Dergisi, 15(43), 87-118.

Arslaner E. ve Erol G. (2017). Alternatif Turizmin Bazı Türleri Üzerine Bir Değerlendirme. Journal of Tourism and Gastronomy Studies, 5(4), 422-438. 
Bahçe A. B. (2011). Küresel Rekabet Sürecinde Devletlerin Kamu Politikaların Belirlemelerinde Teknoloji ve İnovasyonun Rolü. Ekonomi Bilimleri Dergisi, 2(11), 1-17.

Boo E. (1990). Ecotourism: The Potentials and Pitfalls, Country Case Studies. World Wildlife Fund: Washington.

Butovski L. (2012). Sustainable Tourism-A Model Approach, Visions for Global Tourism Industry. Creating and Sustaining Competitive Strategies içinde (s. 4-20).

Cater E. and Lowman G. (1994) Ecotourism: A Sustainable Option?, The Royal Geographical Society, Wiley: Chichester, New York.

Dönmez, Y. ve Türkmen, F. (2015). Turistlerin Satın Alma Kararında Peyzaj Düzenlemelerinin Rolü: Belek Örneği. Turizm Akademik Dergisi, 2(2), 15-27.

Engincan P. (2016). Küresel Kent Mekanları ve Gündelik Yaşam: 'Sanayi Kenti' Olarak Küreselleşen Denizli, II. Uluslararası Kent Araştırmaları Kongresi Bildiriler Kitabı, Ankara.

Erbaş A. (2002). İslam Dışı Dinlerde Hac. Sakarya Üniversitesi İlahiyat Fakültesi Dergisi 5, 110-120.

Eykay İ., Dalgın T. ve Çeken H. (2015). İnanç Turizmi Potansiyeli Açısından Antakya'nın Değerlendirilmesi, Journal of Life Economics (JLE), 2(2), 59-73.

Herzog, T. R., Gray, L. E., Dunville, A. M., Hicks, A. M. and Gilson, E. A. (2011). Preference and Tranquility for Houses of Worship. Environment and Behavior, 45(4), 504-525.

Henderson, J. C. (2002). Managing Tourism and Islam in Peninsular Malaysia. Tourism Management, 24, 447-456.

İbret B. Ü., Aydınözü D., ve Uğurlu M., (2015). Kastamonu Şehrinde Kültür ve İnanç Turizmi, Marmara Coğrafya Dergisi, 32, 239-269.

Kastamonu Kültür ve Turizm Müdürlüğü, Erişim Tarihi: 08.03.2019, https://kastamonu.ktb.gov.tr/TR-63873/inanc-turizmi.html.

Kozak M. A., Evren S. ve Çakır O. (2013). Tarihsel Süreç İçinde Turizm Paradigması, Anatolia: Turizm Araştırmaları Dergisi, 24 (1) ,7- 22.

Levi, D. and Kocher, S. (2012). Perception of Sacredness at Heritage Religious Sites. Environment and Behavior, 45(7), 912-930.

Lopez, L. and Lucrezia (2013) How Long Does the Pilgrimage Tourism Experience to Santiago de Compostela Last?, International Journal of Religious Tourism and Pilgrimage, 1(1), 1-14.

Lopez, L., González, R. C. L. and Fernández, B. M. C. (2017). Spiritual Tourism on The Way of Saint James The Current Situation. Tourism Management Perspectives, 24, 225-234.

Mazumdar, S. and Mazumdar, S. (2012). Immigrant Home Gardens: Places of Religion, Culture, Ecology and Family. Landscape and Urban Planning, 105(3), 258-265.

Mcgettigan, F. and Griffin, C. (2012). Pilgrims Progress: The Changing Nature of Visitors to Religious Sites in Ireland. International Journal of Tourism Policy, 4(2).

McIntyre, G. (1993). Sustainable Tourism Development: Guide for Local Planners. WTO Yayınları: Madrid.

Meagher, B. R. (2018). Deciphering the Religious Orientation of a Sacred Space: Disparate Impressions of Worship Settings by Congregants and External Observers. Journal of Environmental Psychology, 55, 70-80. 
Neitz, M. J. (2013). Insiders, Outsiders, Advocates and Apostates and The Religions They Study: Location and The Sociology of Religion. Critical Research on Religion, 1(2), 129-140.

Okuyucu A. ve Somoncu M. (2013). Türkiye'de İnanç Turizmi: Bugünkü Durum, Sorunlar ve Gelecek, International Conference on Religious Tourism and Tolerance, Proceedings, Konya.

Olcay A. ve Albuz N. (2016). İnanç Turizmi ve Türkiye'nin Tanıtımına Katkısı, Uluslararası Tanıtımda Medya ve Türkiye, Dora Yayıncılık: Bursa.

Ovalı P. K. (2007). Kitle Turizmi ve Ekolojik Turizmin Kavram, Mimari ve Çevresel Etkiler Bakımından Karşılaştııılması, Megaron, 2(2), 64-79.

Sabır H. (2013). Küreselleşen Dünyada Rekabet Politikası ve Gelişmekte Olan Ülkeler, Marmara Üniversitesi Siyasal Bilimler Dergisi, 1,121-134.

Shinde, K. A. (2011). This Is Religious Environment. Space and Culture, 14(4), 448-463.

Taheri, B. (2015). Emotional Connection, Materialism, and Religiosity: An Islamic Tourism Experience. Journal of Travel \& Tourism Marketing, 33(7), 1011-1027.

Tala M. L. and Padurean M. (2008). Dimensions of Religious Tourism, Amfiteatru Economic 10,242-253.

TÜIK, (2018). Ahlat Köyü Nüfus Verileri. Erişim Tarihi: 06.03.2019, http://tuik.gov.tr/UstMenu.do?metod=istgosterge

Türker N., Akça E. ve Uçar M. (2019). Dini Mekanları Ziyaret Eden Turistlerin Seyahat Motivasyonları: Kastamonu İlinde Bir Uygulama, Safran Kültür ve Turizm Araştırmaları Dergisi, 2(1), 111-132.

Urry, J. (2009). Turist Bakışı. Çeviren: E. Tataroğlu, İ. Yıldız. Bilgesu Yayıncılık: İstanbul. 